\title{
Interpreting recent accumulation records through an understanding of the regional synoptic climatology: an example from the southern Antarctic Peninsula
}

\author{
Gareth J. Marshall, John Turner, William D. Miners \\ British Antarctic Survey, Natural Environment Reserach Council, High Cross, Madingley Road, Cambridge CB3 OET, England
}

\begin{abstract}
In this study we correlate temporal features within the electrical conductivity (acidity) traces of four shallow firn cores obtained from the southern Antarctic Peninsula to synoptic-scale variations in the regional climate, as depicted by a numerical weather prediction model. It is demonstrated that the three high-acidity features present within the 1992-93 accumulation correspond to periods of significant precipitation, a hypothesis supported by the association of these events with strong onshore winds, ideal for transporting the biogenically derived sources of precipitation acidity to the core sites. The longitudinal location of depressions within the Bellingshausen Sea is shown to be the principal factor governing the volume of precipitation that they give over the western Peninsula. Annual accumulation in the model is 25\% lower than revealed by the cores; although there are too many uncertainties to provide a definite reason for the deviation, the smoothed model orography and inaccurate land-sea mask are believed to be significant factors. It is postulated that the acidity pattern within southern Peninsula cores may reveal an El Niño-Southern Oscillation signal.
\end{abstract}

\section{INTRODUGTION}

Antarctic ice cores are an invaluable source of proxy climate data, but interpretations of past climate from cores are often necessarily somewhat speculative: for example, does an increase in accumulation represent a greater number of weather systems affecting an area? a strengthening of these systems? a change in circulation such that more systems develop in maritime regions and therefore hold increased moisture? or a decrease in mass-loss mechanisms such as evaporation or wind erosion? However, once we understand the mechanisms within the present climate that govern a region's accumulation, it should be possible, at least for the relatively recent past, to use historical accumulation records to glean information regarding former climate variability and trends.

In this paper we attempt to distinguish the synoptic weather conditions responsible for producing the recent accumulation observed over a region of the southern Antarctic Peninsula from which many cores have been obtained (cf. Peel, 1992). To do this we utilise two disparate sources of climatological data - acidity variability within shallow firn cores, and meteorological parameters derived from a numerical weather prediction (NWP) model - and show that a comparison of the two at a sub-annual temporal resolution can help to explain the former, and to some extent validate the latter. A secondary aim of this study is to compare the annual accumulation from the cores with that obtained from the NWP model.

org/10.3189/1998AoG27-1-610-616 Published online by Cambridge University Press

\section{DATA SOURGES AND METHODOLOGY}

Ice cores

Four shallow firn cores obtained from sites around the

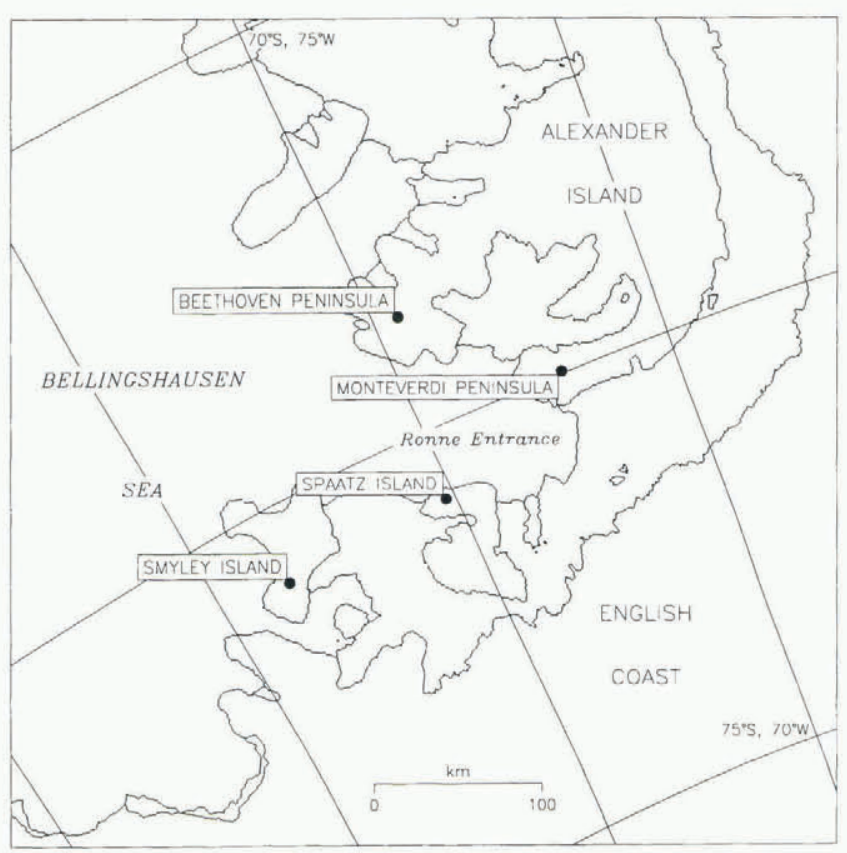

Fig. 1. The southwest Antarctic Peninsula region, showing the four core sites. 
Table 1. Location and elevation of the four core sites

\begin{tabular}{lcccc}
\hline \multicolumn{1}{c}{ Core } & Beethoven & Monteverdi & Smyley & Spaatz \\
\hline Lat./long. $\left({ }^{\circ} \mathrm{S} /{ }^{\circ} \mathrm{W}\right)$ & $71.86 / 74.53$ & $72.51 / 72.10$ & $72.95 / 78.59$ & $72.02 / 75.17$ \\
Actual elevation (m) & 595 & 525 & 305 & 455 \\
$\begin{array}{l}\text { Model cell elevation } \\
\text { (m) }\end{array}$ & -94 & -18 & 242 & 261 \\
& & & & \\
\hline
\end{tabular}

Ronne Entrance region, to the south of George VI Sound, in the southern Antarctic Peninsula are examined as indicators of recent accumulation; the location of these cores, typically less than $100 \mathrm{~km}$ apart, is shown in Figure 1, while
Table 1 details the latitude, longitude and elevation of the core sites. The four cores, each approximately $10 \mathrm{~m}$ long, were acquired in $1 \mathrm{~m}$ lengths between 26 February and 7 March 1996 by a team based on HMS Endurance. The cores were kept frozen and brought back to the U.K. where electrical conductivity measurement (ECM) and stratigraphic records were taken. The former is a proxy indicator of the acid content in the accumulation when it was deposited, and was first described by Hammer (1980). The instrument used for logging the ECM is outlined in Miners and Mulvaney (1995): two electrodes $10 \mathrm{~mm}$ apart with a potential difference of 1500 Vacross the tips are moved along each $1 \mathrm{~m}$ section of core, and the current between the tips sampled approximately every $2 \mathrm{~mm}$. The accuracy of the current measurement is $\pm 1 \mu \mathrm{A}$. Absolute acidity was not
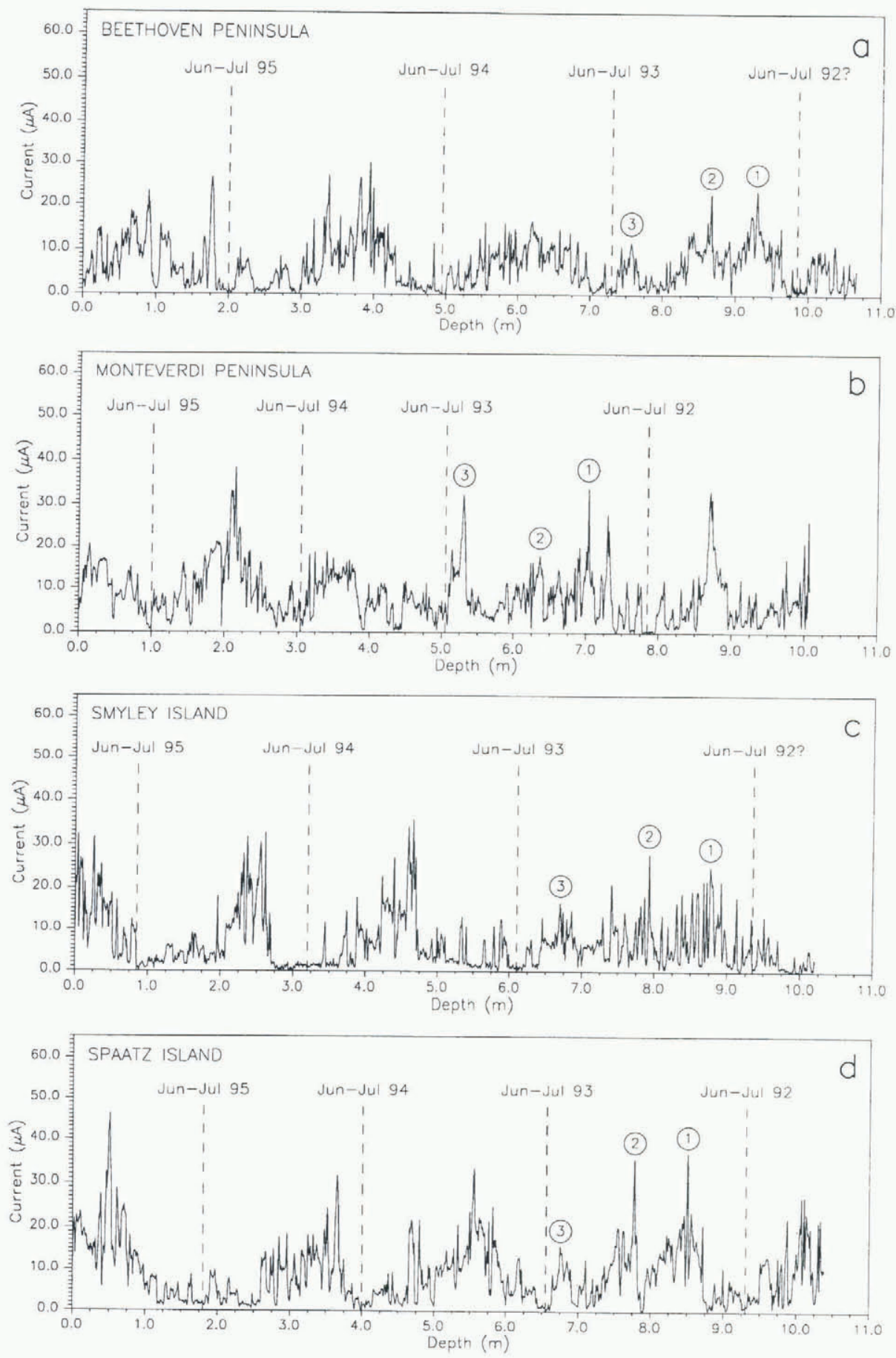

Fig. 2. ECM traces of the four firn cores smoothed using a five-point Gaussian filter: (a) Beethoven Peninsula; (b) Monteverdi Peninsula; (c) Smyley Island; (d) Spaatz Island. The three 1992 93 HAFs are shown. 
derived, but the current is approximately proportional to the square root of the acidity after temperature corrections have been made. Over the Antarctic continent, away from anthropogenic influences, the atmospheric acidity is principally a function of the amount of biogenically derived oceanic dimethyl sulphide (DMS) taken up by an air mass. This is subsequently oxidised in the atmosphere to either methane sulphonic acid (MSA) or sulphuric acid (Mulvaney and others, 1992), prior to being incorporated into snowfall. In addition, there is a small summer seasonal contribution to the acidity from nitric acid.

The four ECM traces are shown in Figure 2, smoothed using a five-point Gaussian filter, and reveal significant variability in acidity. Both observations (e.g. Berresheim, 1987; S. M. Turner and others, 1995) and modelling studies (Arrigo and others, 1997), assuming DMS fluxes are proportional to primary productivity (Berresheim, 1987), indicate a marked seasonal cycle in oceanic DMS to the north and west of the Antarctic Peninsula, the oceanic regions over which the air masses giving the precipitation will pass. The limited data suggest that the period of higher concentrations occurs from October to March/April, with the highest values existent during November-February (cf. S. M. Turner and others, 1995, fig. 10). In addition, in the austral summer the marginal ice zone, a region of high primary biological productivity in the Southern Ocean (e.g. Eicken, 1992), moves closer to the Ronne Entrance as the sea ice retreats; note that on an interannual scale MSA has been found to be positively correlated to sea-ice extent (Welch and others, 1993). Thus, some of the lower-frequency variability in Figure 2 can be interpreted as a number of annual cycles, with acidity highest (lowest) during the summer (winter); the very low winter values are usually used to demarcate annual cycles ( 12 months for a given year), assuming precipitation occurs in both summer and winter.

The annual cycles have been marked in Figure 2. Some of these cycles appear very distinct, while others are less clear and require subjective analysis to locate. After checking for ECM contamination due to breaks in the core, the annual cycle limits were obtained by examining the fine structure of the four traces during the winter periods and using those cores where a particular minimum was best defined to locate it in the cases where it is less well constrained. The significant accumulation of this region ( $>1$ m w.e. $\mathrm{a}^{-1}$ ) means that only two complete winter-winter annual cycles (1993-94, and 1994-95) can be distinguished with certainty for the Beethoven and Smyley cores (Fig. 2a and c, respectively), although a possible winter 1992 is also marked. In contrast, the lower accumulation over the period covered by the cores at the Monteverdi and Spaatz sites (Fig. 2b and d, respectively) is such that winter 1992 clearly lies within the core length. However, an advantage of the high accumulation total is that "deposition noise", the uncorrelated part of two spatially close cores that is principally a function of the relief on snow redistribution through windscouring/snowdrifting, is a relatively small percentage of the total variance. A larger error in determining an accurate annual accumulation from the cores is caused by the "definition noise", the uncertainty introduced by assuming the ECM features that define the winter are exactly 12 months apart. The cumulative total of both types of noise is estimated to be $<10 \%$ of the interannual variance of accumulation for a region exceeding $1 \mathrm{~m}$ w.e. $\mathrm{a}^{-1}$ (personal communication from D. Peel, 1997).
Once the annual cycles were defined, the annual accumulation was calculated using a smoothed depth-density curve for each core. Some ice layers, evidence of surface melting by solar radiation, were observed; however, these were narrow ( $\mathrm{mm}$ scale) and comprised a very small fraction of the total annual accumulation. Due to the greater impact of definition noise, the effect of possible percolation between annual layers was not considered. A coarse check on the positional accuracy of the annual limits at Spaatz Island, using available longer-term accumulation values, is described in the discussion.

\section{ERA data}

European Centre for Medium-range Weather Forecasts (ECMWF) reanalysis (ERA) data used in the study comprised daily precipitation, and 6 hourly $u$ (east-west) and $v$ (north-south) wind components and mean sea-level pressure (mslp) fields (see below), which were obtained for the four model gridcells in which the core sites are located. Comparative studies of ECMWF and other NWP models have generally shown the former to be the best currently available for investigating Southern Hemisphere climate (e.g. Bromwich and others, 1995). The ERA encompasses the 15 year period $1979-93$ and is based on the ECMWF NWP model as it stood at the end of the reanalysis period. NWP models are continually being improved, so the consistency of the ERA makes it ideal for studies of climate variability. The data were obtained from the British Atmospheric Data Centre (BADC) in the format of a global Gaussian N80 grid (160 latitudinal cells $\times 320$ longitudinal cells at the Equator, reducing to 18 at the poles), each model cell being of the order of $100 \mathrm{~km}$ in length. Model precipitation was derived from the forecast part of the reanalysis. A $24 \mathrm{~h}$ mean value is computed every day as the difference between the cumulated predictions $0 \mathrm{~h}$ and $24 \mathrm{~h}$ ahead in time. The ERA wind data were averaged to coincide temporally with the daily precipitation values.

The model orography was also obtained. The real orography has to be smoothed to prevent spectral NWP models from becoming unstable. This leads to significant differences between the model orography and the elevation of the core sites, a problem enhanced because the cores are located at the ice divide - to remove interpretation problems associated with ice flow - so are already at an elevation well above the average for a model gridcell prior to smoothing. Furthermore, the nature and scale of the spectral model mean that the gridcells containing the Beethoven and Monteverdi Peninsula cores lie outside the land mask and actually have a negative altitude in the model (cf. Table 1).

\section{Depression activity}

As a measure of the synoptic climatology in this region, the depression activity within the sector between $45^{\circ}$ and $135^{\circ} \mathrm{W}$ and south of $50^{\circ} \mathrm{S}$ was used. Six-hourly ERA mslp fields were employed as input data for an objective automatic cyclone-tracking system. The tracking algorithm used is essentially that described by Murray and Simmonds (1991a, b), and comprises two main processes: (i) finding the systems, and (ii) subsequently tracking them. Jones and Simmonds (1993) used this technique to produce a climatology of Southern Hemisphere cyclone tracks, while more recently Godfred-Spenning and Simmonds (1996) 


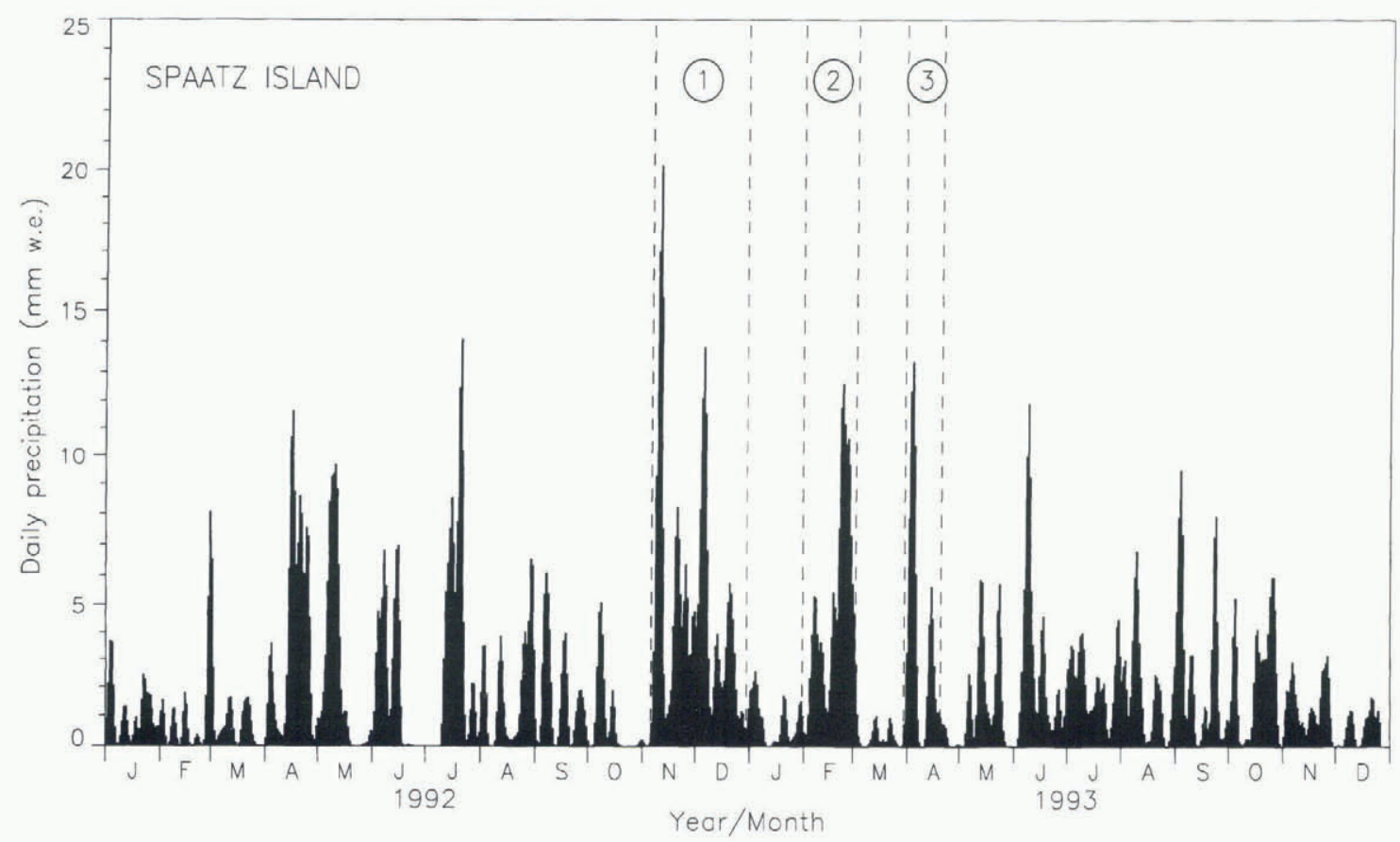

Fig. 3. Smoothed (see Fig. 2) daily precipitation at the Spaatz Island core site for the 1992-93 period obtained from ERA data. The periods associated with the three HAFs are indicated.

compared the associations between these tracks and sea-ice extent.

In this study the measure of depression activity used is "cyclone density", which has been derived from the track statistics. After interpolating the ERA mslp fields to the $47 \times 47$ polar stereographic (PS) grid that the tracking algorithm uses, a count was obtained for the number of systems having a centre within $600 \mathrm{~km}$ of each PS gridpoint for each $6 \mathrm{~h}$ period. The use of a distance parameter, which acts to remove noise and prevents bias caused by latitude/ longitude box counts, means that cyclone density is in fact a measure of the time spent under the influence of a low (Sinclair, 1994), and therefore may have some relation to precipitation; J. Turner and others (1995) demonstrated that most precipitation falling on the western Peninsula was associated with frontal depressions over the Bellingshausen Sea, as had previously been postulated by Bromwich (1988). A distance of $600 \mathrm{~km}$ was used because a depression existent within this region typically has a diameter of $\sim 1200 \mathrm{~km}$ (Turner and others, in press). The mean monthly cyclone density is then obtained with units of $\mathrm{km}^{-2} 10^{-8} \mathrm{~d}^{-1}$.

\section{RESULTS}

The results of this study are divided into three sections.

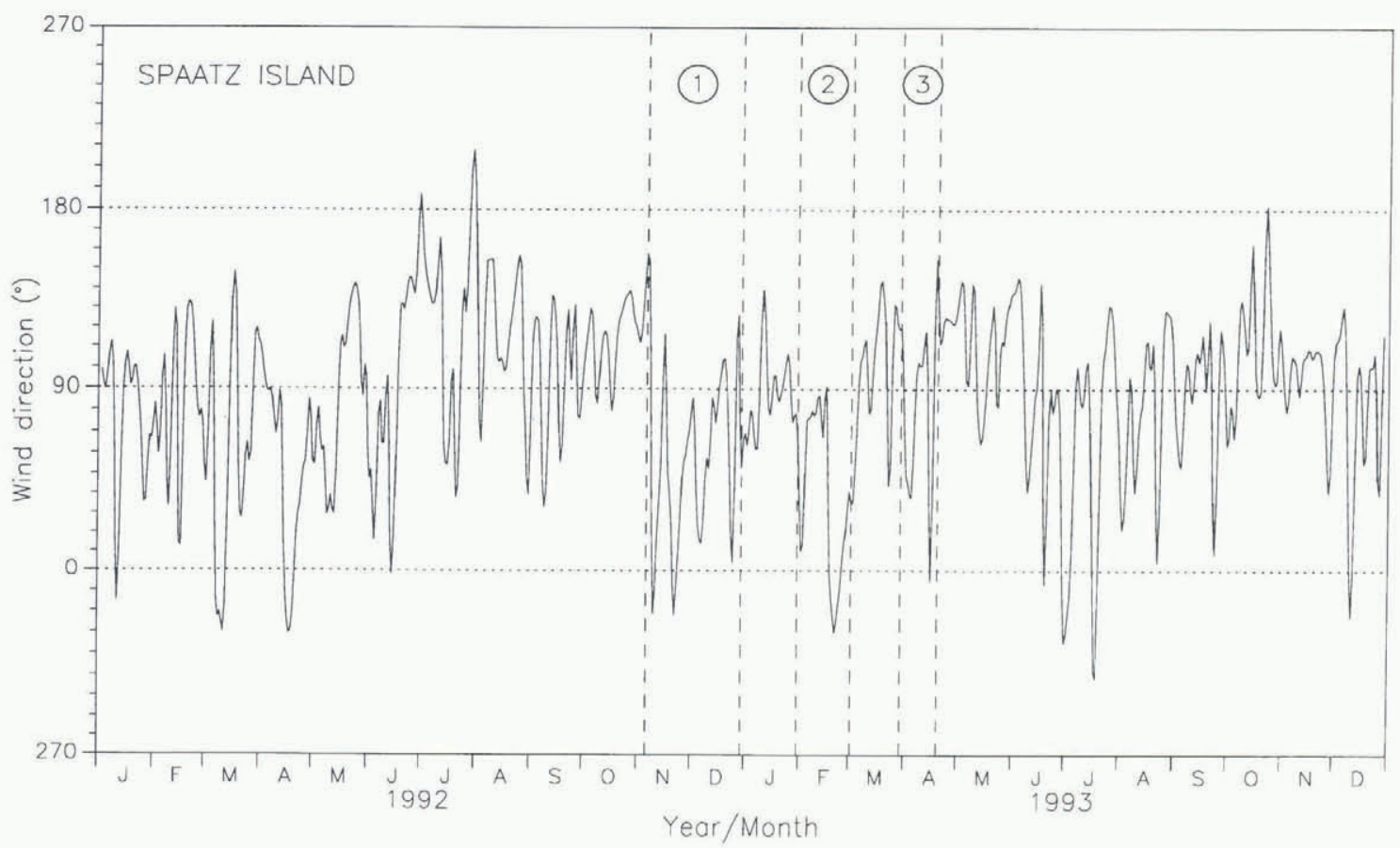

Fig. 4. Smoothed (see Fig. 2) wind direction at the Spaatz Island core site for the 1992-93 period obtained from ERA data. The periods associated with the three HAFs are indicated. 
First, an attempt is made to link the acidity variations revealed by the firn cores to certain changes in the climatic parameters from the ERA. Second, the qualitative relationship between the spatial distribution and magnitude of cyclone density over the Amundsen Sea-Bellingshausen Sea region and model precipitation at the four core sites (the model cells in which these lie) is analyzed. Third, a direct comparison is made between the ERA annual precipitation and that revealed by the firn cores.

\section{Relationship between 1992-93 accumulation acidity variability and ERA synoptic climate}

Only the first of the winter-winter annual cycles (1992-93) overlaps entirely with the ERA, and this paper therefore concentrates on this period. All four cores show three main higher-acidity features (HAFs) in this year (cf. Fig. 2), and their relative heights are similar in all cases, except Monteverdi which reveals the most dissimilar acidity trace along the whole core. The Spaatz Island core will be used as the principal example in this paper: the whole of the 1992-93 accumulation can be observed in this core, and the three HAFs are regionally representative. The annual cycle of DMS concentration, described previously, suggests that the precipitation associated with the HAFs probably fell between October 1992 and April 1993. The smoothed daily ERA model precipitation for Spaatz Island is shown in Figure 3 , and reveals three marked periods of precipitation in this 7 month period: November-December 1992, February 1993 and early April 1993. A comparison with the model wind direction at the Spaatz Island site during OctoberApril (Fig. 4) demonstrates that the wind was generally from the east. During the three periods of high precipitation, the wind direction changed from being from the southeast quadrant (offshore) to being principally a northerly (onshore) and occasionally backing to the northwest. The highest precipitation values are associated with northerlies and to a lesser extent westerlies: there is a correlation coefficient of $-0.61(-0.19)$ between the raw daily precipitation and the deviation of the wind direction away from north (west), which is significant at the $0.01 \%$ level. During the first two of these periods the wind velocity was often seasonally stronger than average, increasing from $\sim 12.5$ to $>21.0 \mathrm{~m} \mathrm{~s}^{-1}$, whereas the wind velocity during the third was actually less than that before and after the period. These changes in precipitation rate and wind regime are used to temporally define the three Spaatz Island core HAF features in Figures 3 and 4, one of which is now described in detail.

(1) November-December 1992: The general trend (with decreasing depth in Figure 2d) of this HAF trace shows a fairly steep rise in acidity, followed by a more gradual decline. There is significant variability within this trend, however, and we surmise that those features of greatest magnitude can be attributed to specific changes in the wind regime, which also reveal themselves as variations within the daily precipitation rate. For example, Figure 3 indicates that very little precipitation occurred during October, so that the very first peak of the HAF feature probably relates to the very high precipitation recorded in early November, which corresponded to a rapid change in wind regime from a gentle offshore southeasterly to a strong onshore northwesterly (cf. Figs 3 and 4). The highest peak of this HAF may correspond to a period in early December when there was a strong northerly at Spaatz Island (cf. Fig. 4) resulting in a second precipitation maximum (cf. Fig. 3). The rapid declines in acidity after these two peaks are associated with a return to lighter offshore winds and a significantly reduced precipitation rate.

The low-acidity features that exist before, between and after the HAFs can also be observed as changes in the parameters shown in Figures 3 and 4. It can be hypothesised that the precipitation that fell prior to HAF No. 1 is that which the model predicted fell in July 1992 (Fig. 3), which as DMS values are low at that time of year had a low acidity content. The low-acidity precipitation between the HAFs appears to be associated with periods of very low precipitation (January 1993 and March 1993; cf. Fig. 3) when winds at the Spaatz Island site were southeasterly in origin (Fig. 4); thus these features appear "short-lived" in the acidity trace (Fig. 2d). Comparing quantitatively the relative proportions of the individual totals of model precipitation and core accumulation associated with the different acidity features suggests that the above interpretation is valid, with the exception that the third HAF must comprise additional precipitation to that which fell in April 1993.

\section{Relationship between monthly cyclone density and ERA model precipitation during 1992-93}

In order to try to understand qualitatively the relationship between synoptic depression activity in the Amundsen SeaBellingshausen Sea region and (model) precipitation in the Ronne Entrance region, cyclone density was examined for those months in 1992-93 when three or more of the four core-site model cells had very high (low) precipitation, defined as one of the five highest (lowest) monthly precipitation totals of the 24 month period at that site. Three (five) months qualified as having very high (low) precipitation; these were November 1992, December 1992 and February 1993 (February 1992, January 1993, March 1993, November 1993 and December 1993). Examples of cyclone density for two months with high and low precipitation in the Ronne Entrance region are illustrated in Figure $5 \mathrm{a}$ and b, respectively. Those months having high precipitation had the cyclone density maximum within the Antarctic circumpolar trough (CPT) located at least $100^{\circ} \mathrm{W}$. In contrast, those months having low precipitation generally had the maximum cyclone density positioned much closer to the Peninsula $\left(\sim 80^{\circ} \mathrm{W}\right)$ or even over it (February 1992, March 1993). The exception is January 1993, but in this case the values of cyclone density indicate that essentially no regional synoptic activity occurred over the Bellingshausen Sea during this month. Note that all these months of extreme precipitation occurred during summer (NovemberApril), and cyclone-density standard deviation was found to be $\sim 40 \%$ higher in this region in summer than in winter for the entire ERA period. There is little variation in the latitude of the cyclone-density maxima: all the systems lie within the CPT between $65^{\circ}$ and $70^{\circ} \mathrm{S}$. The maximum cyclone density is actually slightly lower for months having high precipitation.

\section{Annual accumulation}

Results of a comparison of the 1992-93 core accumulation at Spaatz Island (1.27 $\mathrm{m}$ w.e.) and the precipitation predicted by the ECMWF model from July 1992 to June 1993 (0.93 m 


\section{(a) December 1992}

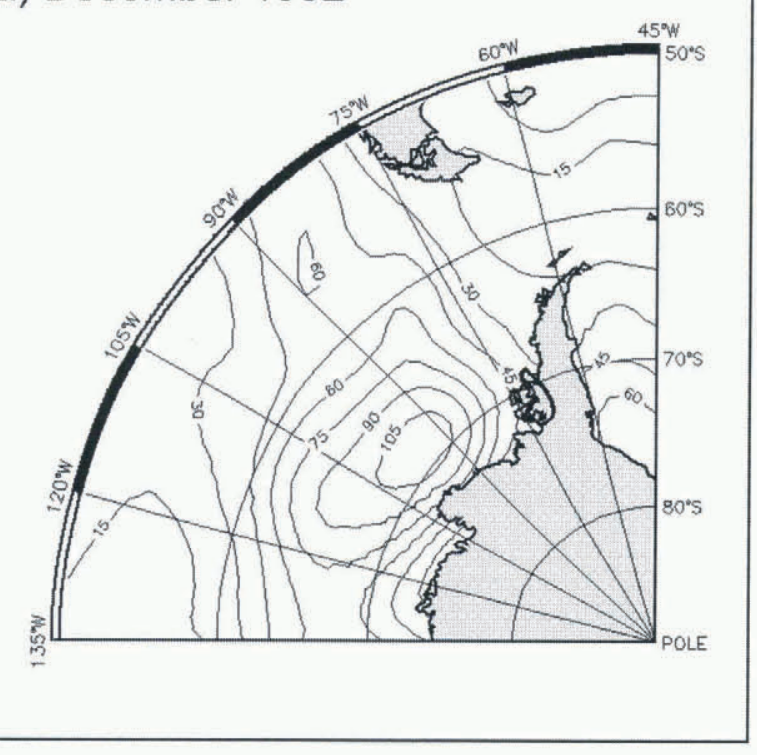

(b) November 1993

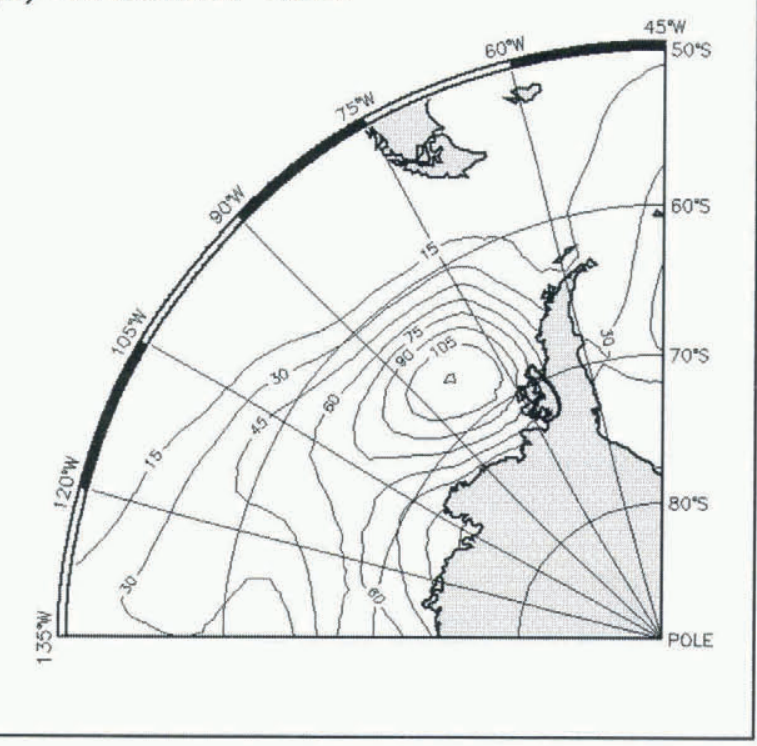

Fig. 5. Examples of the spatial pattern of monthly cyclone density over the Bellingshausen Sea associated with (a) high precipitation and (b) low precipitation at the four core sites. Units are number of systems per $\mathrm{km}^{2} \times 10^{-8} \mathrm{~d}^{-1}$ within $600 \mathrm{~km}$.

w.e.) demonstrate that the latter amounts to only $73 \%$ of the former. Two longer-term means for the annual accumulation at Spaatz Island are quoted in the literature: $1.25 \mathrm{~m}$ w.e. (Peel and Clausen, 1982) and $1.15 \mathrm{~m}$ w.e. (Wolff and Peel, 1985). These compare favourably with the 3 year mean from the $10 \mathrm{~m}$ core $(1.22 \mathrm{~m})$. The three annual accumulation figures derived from the ECM trace all lie within $15 \%$ of this mean, suggesting that there are no significant errors in the location of the winter minima and that the 1992-93 core accumulation is accurate. Possible causes of the differences between this value and the model precipitation are outlined in the discussion.

\section{DISGUSSION}

During the July 1992-June 1993 period, the ERA data revealed that high precipitation at the four core sites is generally associated with strong northerlies and to a lesser extent westerlies over the Ronne Entrance region, a circulation that occurs when a cyclone over the Bellingshausen Sea is centred at $\sim 100^{\circ} \mathrm{W}$ (Fig. $5 \mathrm{a}$ ) - systems existent at this longitude are able to draw temperate mid-latitude air towards the base of the Peninsula in a strong meridional flow - and the duration of the high-precipitation event is related to the existence of blocking high pressure over the northwest Weddell Sea that prevents the low from tracking further northeast around the top of the Peninsula (Turner and others, 1998). However, the slight negative correlation between the maximum mean monthly cyclone density and precipitation at the core sites again emphasises the conclusion that it is the relative longitudinal position of a depression over the Bellingshausen Sea, rather than its duration or distance from the coast, that is the principal factor governing the volume of precipitation it gives over the western Peninsula.

With regard to the Spaatz Island ECM trace, we hypothesise that the three HAFs comprise snow that fell during the three major precipitation events (the third HAF includes additional precipitation, assuming the relative proportions of precipitation and accumulation in the different features are quantitatively directly comparable). This conjecture is supported by the fact that the winds associated with these events are predominantly onshore and so have passed over the oceanic DMS source regions, whereas those outside the temporal extent of these events are generally offshore; the use of back trajectories will provide quantitative data. Moreover, Berresheim (1987) stated that the DMS emission rate into the atmosphere is a general function of wind velocity. During the third high-precipitation event (April-May 1993) wind speeds were significantly lower than during the previous two, and this, combined with a lower background oceanic DMS concentration, probably accounts for the smaller acidity peak of HAF No. 3 .

The annual ERA model precipitation forJuly 1992-June 1993 was $25 \%$ too low when compared to the accumulation derived from the Spaatz Island core. Previously, Genthon and Braun (1995) analyzed 6 years of ECMWF precipitation data (not from the reanalysis) over Antarctica, and found fairly good agreement between the prediction and observational means. For example, at Byrd Station $\left(80.5^{\circ} \mathrm{S}\right.$, $120.0^{\circ} \mathrm{W}$ ), the nearest point of comparison to the Ronne Entrance region, the model under-predicted precipitation by $\sim 40$ mm year $^{-1}$, equivalent to $25 \%$, although the years of prediction and observation were not identical. There are many possible reasons for the discrepancy, including that (i) the two parameters are not identical, and (ii) one of the parameters is a point-source, while the other is averaged over $\sim 10000 \mathrm{~km}^{2}$. However, the 1992-93 core accumulation value is similar to long-term means, so definition noise in the ECM trace (inaccurate temporal location of winter 1992-93) is not considered a major contributing factor, nor is deposition noise. Thus, most of the "error" probably lies within the model precipitation, and other workers have found the ERA forecast data to be "too dry". The smoothed model orography may also be a significant factor: a thirdorder best-fit line through a plot of the annual precipitation vs model elevation for all west-facing model gridcells in the 
southwest Antarctic Peninsula region indicates that if the elevation of the Spaatz Island gridcell $(261 \mathrm{~m})$ were increased to that of the core site $(455 \mathrm{~m})$ then the accumulation might be expected to rise by $\sim 0.1 \mathrm{~m}$ w.e. The resultant slopes in the model will also be smoother than reality, especially in a relatively high-elevation gradient region like the Peninsula, and this will affect the rate at which precipitation falls from an air mass forced to rise as it moves upslope, and thus the spatial distribution of that precipitation. The exact effect on model precipitation for a gridcell below sea level and outside the land mask must remain conjecture; for example, part of the error will be caused by an incorrect surface heat flux.

Recently, Cullather and others (1996) investigated the link between interannual variations in precipitation, as measured using atmospheric moisture fluxes derived from ECMWF data, across a sector of West Antarctica. These authors found that "The positioning of the Amundsen Sea Low [was the] catalyst for the observed ENSO [El NiñoSouthern Oscillation] precipitation variability ... The annually averaged climatological low is the result of wintertime positioning in the Ross Sea and the summertime low pressure that forms to the west of the Antarctic Peninsula. The annually averaged low thus appears to be the dominance of one season over another". During ENSO warm events the low moved further east, giving more precipitation over the Peninsula. As this study has shown that the summer acidity within the Ronne Entrance firn cores may be related to the longitude of cyclones over the Bellingshausen Sea, it can be argued that the acidity pattern may represent a further ENSO indicator within western Peninsula firn cores, in addition to annual accumulation, although a core spanning several decades would be required to substantiate this. A positive link between MSA and ENSO warm events over the last 60 years has been reported from a firn core at the South Pole (Legrand and FenietSaigne, 1991), but Pasteur and others (1995) were unable to demonstrate a similar relationship for a core acquired on the eastern side of the Peninsula. In the latter case, the precipitation is derived principally from systems over the Weddell Sea, and, in contrast to the Bellingshausen SeaAmundsen Sea, no significant variation in the regional mslp field (cf. Cullather and others, 1996, fig. 5) is observed between ENSO cold and warm events.

In order to substantiate the principal hypothesis of this paper, future work will need to utilise a much greater number of annual ECM traces to confirm the climatic correlations observed here. Moreover, additional accumulation parameters (chemistry/isotopes) will be utilised to validate the accuracy of dating using the ECM traces. The relationship between the longitude of individual depressions in the Bellingshausen Sea (as "observed" in the ECM record) and the annual climatological Amundsen Sea Low also needs to be examined in detail. Satellite imagery, from which the frontal structure of depressions can be obtained, can be used to further study the association between cyclone location and precipitation over the western Peninsula. An extension of the firn-core network is planned for late 1997.

\section{ACKNOWLEDGEMENTS}

We are grateful to S. Leonard and W. Connolley for helping to extract the data fields from the ERA and to R. Mulvaney for advice regarding the shallow-core data. We thank the BADC for making the ERA fields available to us. Thanks also to P. Harper and F. Hindle who collected the cores.

\section{REFERENCES}

Arrigo, K. R., D. L. Worthen, M. P. Lizotte, P. Dixon and G. Dieckmann. 1997. Primary production in Antarctic sea ice. Science, 276 (5311), 394-397.

Berresheim, H. 1987. Biogenic sulfur emissions from the subantarctic and Antarctic oceans. 7. Geophys. Res., 92(D11), 13,245-13,262.

Bromwich, D. H. 1988. Snowfall in high southern latitudes. Rev. Geophys., 26(1), 149-168.

Bromwich, D. H., F. M. Robasky, R. I. Cullather and M. L. van Woert. 1995. The atmospheric hydrologic cycle over the Southern Ocean and Antarctica from operational numerical analyses. Mon. Weather Rev., 123(12), 3518-3538.

Cullather, R. I., D. H. Bromwich and M. L. van Woert. 1996. Interannual variations in Antarctic precipitation related to El-Niño-Southern Oscillation. J. Geophys. Res., 101 (D14), 19,109-19,118.

Eicken, H. 1992. The role of sea ice in structuring Antarctic ecosystems. Polar Biol., 12 (1), 2-13.

Genthon, C. and A. Braun. 1995. ECMWF analyses and predictions of the surface climate of Greenland and Antarctica. 7. Climate, 8(10), 2324 2332.

Godfred-Spenning, C. R. and I. Simmonds. 1996. An analysis of Antarctic sea-ice and extratropical cyclone associations. Int. f. Climatol., 16(12), $1315-1332$.

Hammer, C. U. 1980. Acidity of polar ice cores in relation to absolute dating, past volcanism, and radio-echoes. J. Glaciol., 25(93), 359-372.

Jones, D. A. and I. Simmonds. 1993. A climatology of Southern Hemisphere extratropical cyclones. Climate Dyn., 9(3), 131-145.

Legrand, M. and C. Feniet-Saigne. 1991. Methanesulfonic acid in south polar snow layers: a record of strong El Niño? Geophys. Res. Lett., 18(2), 187-190.

Miners, W. D. and R. Mulvaney. 1995. Electrical logging and initial dating of ice cores from Berkner 94/95. In Oerter, H., ed. Filchner-Ronne Ice Shelf Programme. Report 9. Bremerhaven, Alfred Wegener Institute for Polar and Marine Research, 64-66.

Mulvaney, R., E. C. Pasteur, D. A. Peel, E. S. Saltzman and P. -Y. Whung. 1992. The ratio of MSA to non-sea-salt sulphate in Antarctic Peninsula ice cores. Tellus, 44B(4), 295-303.

Murray, R. J. and I. Simmonds. 1991a. A numerical scheme for tracking cyclone centers from digital data. Part I. Development and operation of the scheme. Aust. Meteorol. Mag., 39(3), 155-166.

Murray, R. J. and I. Simmonds. 1991b. A numerical scheme for tracking cyclone centers from digital data. Part II. Application to January and July general circulation model simulations. Aust. Meteorol. Mag., 39(3), $167-180$.

Pasteur, E. C., R. Mulvaney, D. A. Peel, E. S. Saltzman and P. -Y. Whung. 1995. A 340 year record of biogenic sulphur from the Weddell Sea area, Antarctica. Ann. Glaciol., 21, 169-174.

Peel, D. A. 1992. Ice core evidence from the Antarctic Peninsula region. In Bradley, R. S. and P. D. Jones, eds. Climate since A.D. 1500. London and New York, Routledge, 549-571.

Peel, D. A. and H. B. Clausen. 1982. Oxygen-isotope and total beta-radioactivity measurements on $10 \mathrm{~m}$ ice cores from the Antarctic Peninsula. 7. Glaciol., 28(98), 43-55.

Sinclair, M. R. 1994. An objective cyclone climatology for the Southern Hemisphere. Mon. Weather Rev., 122 (10), 2239-2256.

Turner, J., T. A. Lachlan-Cope, J. P. Thomas and S. R. Colwell. 1995. The synoptic origins of precipitation over the Antarctic Peninsula. Antarct. Sci., 7(3), 327-337.

Turner, J., S. Leonard, T. Lachlan-Cope and G. J. Marshall. 1998. Understanding Antarctic Peninsula precipitation distribution and variability using a numerical weather prediction model. Ann. Glaciol., 27 (see paper in this volume).

Turner, J., G. J. Marshall and T. A. Lachlan-Cope. In press. An analysis of synoptic-scale low pressure systems within the Antarctic Peninsula sector of the circumpolar trough. Int. F. Climatol..

Turner, S. M., P. D. Nightingale, W. Broadgate and P. S. Liss. 1995. The distribution of dimethyl sulphide and dimethylsulphoniopropionate in Antarctic waters and sea ice. Deep-Sea Res., 42 (4-5), Part II, 1059-1080.

Welch, K. A., P. A. Mayewski and S. I. Whitlow. 1993. Methanesulfonic acid in coastal Antarctic snow related to sea ice extent. Geophys. Res. Lett., 20 (6), 443-446.

Wolff, E.W. and D. A. Peel. 1985. Closer to a true value for heavy metal concentrations in recent Antarctic snow by improved contamination control. Ann. Glaciol., 7, 61-69. 